\title{
A escola: um projeto visando ao ensino interdisciplinar e transversal
}

\begin{abstract}
Hilda Rabelo de Olievira Alberto N. Senapeschi

Palavras-chave: ensino

fundamental;

interdisciplinaridade; pedagogia

por projeto; intertextualidade.

\section{Resumo}

O trabal ho aqui apresentado foi desenvolvido com crianças na faixa de sete anos, al unos da 1 1 a série do ensino fundamental da Escola Estadual "Prof. Bento da Silva César", na periferia deSão Carlos (SP). O objetivo do projeto foi trabal har conteúdos curriculares sem quefossem fragmentados, deixando quea interdisci plinaridade e a transversal idade estivessem presentes durante todo o seu transcorrer. Procurou-se, também, desenvolver nas crianças o gosto pela escola e pel o trabal ho. Os al unos estiveram o tempo todo muito motivados, e questões curriculares como al fabetização e leitura, medidas e aritmética, ciências emeio ambiente, desenho e criatividade, artes, trabal ho erespei to mútuo, ética e pesquisa estiveram sempre presentes, tratadas dentro da metodologia proposta para o projeto.
\end{abstract}

\section{Introdução}

As evidências têm mostrado que é grandea distância entre teoria e prática na escola.

Também, no âmbito pedagógico, as contradições são bastante evidentes. Difundeseumconhecimento fragmentado eexige-se umindivíduo por inteiro, como setem mostrado naliteratura. Não param por aí as contradições. Segundo Kleiman e Moraes (1999, p. 13-14), procura-sefazer com queo al uno memorize o máximo de teoria possível, e cobra-sedele, no mercado detrabal ho, a formação práticanecessária euma boa atuação na empresa. As mesmas autoras ai nda salientam que se cobra dos alunos o espírito coletivo de solidariedade e se dá na escola ênfase bem mai or ao trabal ho individual.
Elas vão além, em suas consi derações, colocando que:

O ensino da leitura refletetambém esta pedagogia da contradição: fragmenta-seo texto para que se aprenda a perceber o todo, procura-sefazer com que o al uno responda somente o que está previsto na leitura do professor ou do autor do livro didático e exige-se um leitor crítico e participativo. O aluno escreve textos de opinião sem ter formado uma opinião; faz uma "interpretação livre", já cerceado, sem liberdade e, muitas vezes, sem leitura. Ele "lê" sem entendimento, interpreta sem ter lido e realiza atividades sem nenhuma função na sua realidade sociocultural. Quanto ao professor, fracassa em desenvolver projetos críticos e criati vos em todos os níveis e áreas porque seus alunos não são leitores e nada faz a respeito, pois 
formou-se dentro da visão de que a leitura e a escrita são atribuições exclusivas dos professores de língua portuguesa, que, por sua vez, não conseguem dar conta sozinhos da empreitada.

Foi na busca de um projeto diferenciado que a professora-pesquisadora, responsável por uma sala de 1aㅡ série do ensino público fundamental, num bairro de periferia da cidade de São Carlos (SP), procurou evitar todas estas contradições, buscando um projeto em que 0 ensino nãocompartimentado se fizesse presente, além de possi bilitar aos al unos umaformação prática eo trabal ho coletivo, solidário, quelhes permitissegostar de ir à escola, sentir prazer einteresse.

Para Alves (2002, p. A3) "desde que o objetivo da educação é permitir que vivamos melhor, nossas escolas deveriam tomar a natureza como mestra".

Foi a partir deste texto do consagrado educador que decidimos pela publicação da pesquisa desenvolvida, quecontribuiu para que o al uno setornasse mais sensível à be leza da natureza, que a sua sensibilidade ficasse mais educada, que suas possibilidades de espanto e al egria fossem aumentadas e, final mente, que se ensinasse uma ferramenta de uso prático, aumentando o poder do al uno sobre o mundo que o cerca, ainda conforme Alves, ao se referir a Hume em seu livro Investigação sobre o entendimento humano.

O tema de uma pesquisa não nasce do nada; ele sempre tem uma razão, um misté rio que se deseja desvendar, o que exige, quase sempre, para isso se torne realidade devemos nos tornar sensíveis a cores eodores das coisas desconhecidas, conforme Savedra e Cava (2000, p. 127).

No presente trabalho, procurou-se construir a partir de um texto - no caso, uma historinha infantil - uma rede de conhecimentos que pudesse remeter os alunos de 1a série do ensino fundamental às diversas disciplinas, não apenas a partir da intertextuali dade, que permiteapontar para diversos temas do conjunto de disciplinas do programa escolar, mas também para discutir temas como a sol idariedade e a ética, entre outros.

A intertextualidade permitiu que assuntos de diversas disciplinas fossem introduzidos aproveitando-se da historinha contada, constituindo uma experiência muito bem-sucedida relacionada com a área deeducação.
Os professores sentem necessidade e desejo de incluir a discussão de val ores no currículo da escola fundamental, mas encontram dificuldades em fazêlo.

Outra dificul dade freqüentemente encontrada pelos professores é a de pensar interdisciplinarmente, porque toda a sua aprendi zagem realizou-se dentro de um currículo compartimentado. Eles não se sentem aptos a desenvol ver projetos temáticos, que pressupõem intenso trabal ho coletivo e podem implicar a perda da predominância detarefas e aval iações indi vidualizadas.

Ao elaborar o presentetrabal ho, procurou-se dar aos professores, particularmente aos do ensi no fundamental, a oportunidade de conhecer um projeto simples, acessível, que pode ser utilizado com relativa facilida de, em que a transversalidade (mediante a inclusão e discussão de valores) e a interdisciplinaridade (por meio de conteúdos diversificados enão-compartimentados) estivessem presentes, colaborando para a melhoria do ensino.

Para o desenvolvimento do trabalho, procurou-se dar a ele uma abordagem etnográfica, não se restringindo apenas ao que se passa no âmbito da escola, mas sim relacionando-o com o que éaprendido dentro e fora da mesma (Lüdke, André, 1986, p. 11-17).

O trabalho manual desenvolvido em conjunto pelos alunos tornou-se um processo abrangente que envolveu toda a comunidade, desde gestores e professores até al unos e pais, com planejamento e diál ogo, negociação e(auto-)aval iação constantes por parte de todos, para o sucesso do projeto.

A EEPG "Prof. Bento daSilva César" está localizada no bairro Arnon de Mello, no município de São Carlos (SP), oferecendo ensino regular de $1^{\underline{a}}$ a $4^{a}$ série do ensino fundamental, nos períodos da manhã e da tarde, desde 1995. São 15 salas no total, com $50 \mathrm{~m} 2$ cada uma, em média, e com 30 classes regulares, mais uma de recursos, total izando 1.029 alunos.

No ano passado, a escola procurou fazer um trabal ho col etivo, interdisciplinar e integrado, tendo sempre como meta a mel horia da qual idade de ensino ea formação do aluno como cidadão crítico e participativo.

A clientela da escola tem pais com, no máximo, 1ㅇgrau completo (mais de $80 \%$ ) e baixa renda familiar - a grandemai oria, até quatro salários mínimos. Os al unos residem com os pais - mais de $93 \%$. 
Os pais são operários, pedreiros, auxiliares deserviço, eas mães, domésticas e do lar, todos em números bem acentuados.

\section{0 trabalho desenvolvido}

O projeto foi desenvolvido com crianças na faixa de 7 anos, al unos da 1 a série do ensino fundamental da escola estadual "Prof. Bento da Silva César", na periferia de São Carlos.

O objetivo do projeto foi o de trabaIhar conteúdos curriculares sem que os mesmos fossem fragmentados, deixando que a interdisciplinaridade e a transversal idade estivessem presentes durante todo o seu desenvolvimento.

Ambas apontam a complexidade do real e a necessidade de considerar a teia de relações entre seus diferentes e contraditórios aspectos. Mas diferem uma da outra, uma vez que a interdisciplinaridade refere-se a uma abordagem epistemológica dos obje tos de conhecimento, enquanto a transversalidade diz respeito principalmente à dimensão da didática (PCN Parâmetros Curriculares Nacionais - 1aa a 4ª série, 1997, p. 40).

Procurou-se, também, desenvolver nas crianças o gosto pela escol a e pel o trabal ho.

Para que tai s objetivos fossem al cançados, partiu-se de uma historinha infantil "A galinha ruiva" -, que levou à idéia de plantar o milho de verdade, dele cuidar e fazer um bolo para a classe toda comer.

O projeto foi iniciado em 10 de março e concluído no dia 28 de julho, quando ocorreu a festa final, real izada com o bolo de milho e a apresentação do teatro pelos alunos.

O trabal ho desenvolvido, desde o início do projeto, foi criteriosamente acompanhado mediante rel atório escrito, fotos, desenhos efilmagem eteveinício coma históriada galinha ruiva (adaptação), contada aos alunos:

Enquanto contava a história da galinha ruiva, gesticulava as brincadeiras folclóricas: cobra-cega, amarel inha, canções de roda, pular corda.

Houve uma hora em que o macaco come çou a pular de gal ho em gal ho, mas os outros amigos não conseguiam fazer igual. Como o macaco era muito amigo e não queria brincar sozinho, resolveu descer do gal ho, e combinaram outras brincadeiras das quais todos pudessem participar. Foi aí que resolveram visitar dona galinha.

Chegando na casa de dona galinha, ela abraçava cada um e imediatamente oferecia-lhes um bolo.

Mas para isso tinha que ir ao milharal. Mas, ao colher as espigas de milho, sua asinha começou a doer. Foi quando decidiu pedir ajuda aos seus amigos e el es negaram dizendo que só queriam brincar. Mas mesmo assim ela continuou a pedir ajuda para levar o saco com espigas de milho, descascar, lavar, ralar e mexer a massa, enenhum pedido teveresposta afirmativa.

Assim que o bolo assou, o cheiro saiu pelas portas e janelas e os animais o sentiram. A dona galinha perguntou quem a ajudaria a comer aquele lindo e delicioso bolo. Nesta hora todos queriam, mas dona gal inha não deu nenhum pedaço e recapitulou todos os pedidos que havia feito e para os quais não obteve a colaboração.

Assim, os animai foram embora com uma grande lição".

O relatório foi redigido de forma a permitir quetoda pessoa que o leia consigainterpretar o que ocorreu no grupo estudado tão apropriadamentecomo sefosseum membro do próprio grupo.

Já durante a história os alunos eram esclarecidos de que antigamente não havia liqüidificador eque o forno era de barro ou tijolo, sendo necessário col ocar lenha para aquecêlo, levando-os a constatar os avanços tecnológicos.

O projeto permite ver a sala de aula como um lugar para a comunicação de informações, para o estabelecimento de relações sociais e para a expressão da identidade e de atitudes. Ou seja, éo espaço de convergência do cognitivo, do social e da expressão pessoal na construção de redes de conhecimento (Kleiman, Moraes, 1999, p. 50).

Ao final, os alunos gostaram da história - al guns acharam o final triste, outros, engraçado - e entenderam que os animais deveriam ter colaborado com "dona" galinha.

Quando os alunos disseram isso, enfatizou-se o quanto é importante a colaboração - tudo fica mais gostoso, mais fácil - e incentivou-se a colaboração em casa; então, sugerimos a el es que, todos 
juntos, plantássemos mil ho de verdade e, depois que o milho crescesse, fizéssemos um bolo.

Os sorrisos e as pal mas foram tão cal orosos quenem se precisou de palavras. Estava iniciado o projeto.

Durante o desenvolvimento do trabaIho, foram tiradas fotos que serviram para manter a memória do projeto:

- marcando os espaços entre as covas e plantando o milho; milho;

- observando eregando a plantação de

- registrando, por meio de desenhos, os acontecimentos anteriores;

- observando o milho in vitro;

- replantando o mil ho na terra;

- colocando o esterco no pé de mil ho;

- comparando os tamanhos entre mi-

Iho/milho e milho/al unos;

- observando e cuidando do milho;

- o surgimento dos pendões.

Ainda para que os próprios alunos acompanhassem o desenvolvimento do trabalho, registrando as etapas, conformeeles, próprios viam, fizeram desenhos em sala:

- registrando a história da gal inha ruiva;

- marcando os espaços entre as covas e plantando o milho; milho;

- observando eregando a plantação de

- colocando água com sabão (para ma tar os bichinhos);

- colocando esterco;

- comparando os tamanhos entre miIho/milho e milho/al unos;

- observando os pendões;

- fazendo a colheita de milho.

No dia 10 de março, o milho foi plantado por todos, com explicações prévias sobre os vários tipos de milho, a necessidade do "veneno" no milho, os cuidados com a segurança e higiene e a importância da aprendizagem.

Dia 10 de março de 1999 nós plantamos o milho, mas antes falei sobre vários tipos de medidas (o metro, e mostrei a régua que eu usava; centímetros, emostrei a ré gua que eles usavam) e que antigamente muitos usavam outras mane ras para marcar tamanho, como "palmos". Neste momento medi as pal mas das mãos dos alunos e a minha também. Eu não fal ava a medida: eles tinham que descobrir, e se al guém não conhecia os numerais, o colega fal ava. Depois falei de "passo", quetambém foi muito utilizado para vários tipos de plantações equeera essa distância (medida) que iríamos usar para plantar o miIho. Escol hi o aluno mais alto da classe, porque os outros eram muito pequenos e, com os seus "passos", o mil ho ficaria muito próximo um do outro. E assim foi escolhida uma menina, que, com um pedaço grande de cabo de vassoura, fazia as covas, ea cada passo as crianças contavam.

Tivemos (eu e a coordenadora Anézia) todo o cuidado, porque o mil ho estava com "veneno".

Comentei sobre anecessidade do uso deste "veneno" para a conservação dos grãos e pedi para que todos col aborassem enão os colocassem na boca, ol hos, nariz eouvido; ao mesmo tempo, lembrei que eles já não eram mais bebês, e sim que já estavam crescendo e aprendendo muitas coisas. Isso fez com que eles se sentissem mais importantes. Depois disso, tomei precauções, pondo uma luva em minhas mãos e nas das crianças, sacolas plásticas. Cada uma recebeu um grão de mil ho e, em equipes de três ou quatro (eles próprios montaram as equipes), o colocou na cova.

A pós realizada a plantação, retiramos as "supostas" luvas, lavamos as mãos com detergente e fomos para a classe. Ao che garmos, peguei três vidros com algodão e água e col oquei o mil ho em cada um deles - dei ênfasenagrandeimportância daágua para os seres vivos (Do rel atório queacompanhou o trabal ho).

No mesmo dia, o milho foi plantado in vitro eas crianças regi straram com desenhos todas as atividades. Também o desenvol vimento do milho foi acompanhado com desenhos efotos. Os desenhos permitiam que os al unos registrassem o que estavam observando e pudessem comparar.

Neste mesmo momento, as crianças registraram, através de desenhos, o que fizeram lá fora (plantação de milho) e o que fizemos dentro da classe com os vidros. Coloquei os vidros em cima do armário, perto da janela, onde os grãos receberiam o sol, e expliquei a necessidade do mesmo para o crescimento da planta. Como havia faltado um aluno, no outro dia ele foi regar a plantação do milho. Novamente falei sobre a importância desse vegetal.

E a cada dois ou três dias os alunos recebiam em suas mesas os vidros. As crianças ficavam encantadas, pois contavam realmente o que estava acontecendo com o 
milho e registravam exatamente como viam, exceto al gumas, que col ocavam flores e as faziam mai or do que viam; então, eu fal ei que o desenho estava lindo, mas o importante era desenhar o que real mente estavam vendo, o que estava acontecendo com o mil ho (Trecho do relatório).

As diferenças entre o estági o de desenvolvimento do milho in vitro e na terra foram explicadas com base na diferença de densi dade entre a terra e o al godão (fal ando quea terra era muito mais pesada queo algodão).

Passaram-se mais dez dias e fomos visitar o milho na terra. Eles ficaram tristes, pois ainda não havia crescido.

Comentei sobre o processo decrescimento na terra, queera muito mais pesada do que o al godão, e por isso acontecia a demora (Trecho do relatório).

A importância da água foi sempre valorizada. As partes das plantas e suas funções foram sempre discuti das e mostradas aos al unos. A presença de "bichinhos" no milho serviu para discutir a questão dos inseticidas, a necessi dade delavar bem os alimentos antes de ingeri-los.

Outras estavam discutindo que a planta mais bonita era da sua equipe e aí observaram que uma das fol has do mil ho estava destruída pelos bichinhos. Foi então que comentei sobre os "venenos" que muitos agricul tores têm queusar para que não seestraguea plantação eque, por isso, era necessário lavar bem os alimentos (Trecho do relatório).

Também, inseticidas naturais foram preparadose, depois, foi apresentada a sua importância. Paral el amente, os al unos começaram a preparar a dramatização da historinha da galinha ruiva.

E, no dia 27 de abril, fomos fazer uma visita de rotina e aproveitamos para regar a plantação. Cada aluno pegou o regador ecuidou do milharal ... Somente uma al una não quis fazêlo, e eu não a obriguei, só comentei: "Que pena! A planta está tão triste!".

$\mathrm{E}$, durante este trabal ho, vimos que os bichos estavam estragan do as fol hagens. Tinha insetos grandes, parecidos com uma barata pequena e de pernas grandes. Os alunos ficaram muito tristes, enovamente falei dos "venenos" utilizados nas grandes lavouras e da necessi dade de lavarem bem as frutas. Daí perguntei: "O que vocês acharam dos bichos na plantação de milho?" Alguns responderam: "São sem educação!", "Não têm respeito!"

E aproveitei para comentar sobre inseticidas naturais, isto é, os que matam os bichos e não matam as plantas nem as pessoas.

Portanto, falei do fumo de rolo, feito do mato que tem uma fol ha grande everde, e quefoi muito usado para matar bichinhos. Essa informação eu obtive de uma revista, da qual não tenho os dados no momento, e, também, de outras pessoas. O que eu não lembrava era de como preparar o fumo para col ocar na planta. Fui conversar com a diretora Leni, que tem experiências. Ela fal ou de outras manei ras naturais decombater os insetos, tais como cinza e sabão.

Pedi para ela tirar fotos dos bichos que estavam na folha do milho (Trecho do relatório).

Os al unos novos queentraram na escola foram incentivados a participar e col aborar. Um aluno repetiu a experiência em casa plantando feijão. Os pais gostaram muito:

"Minha filha semprefala quenão vêa hora que tenha milho, pois quer fazer o bolo". A mãe ainda disse: "Filha, eu faço bolo de fubá pra você, eela respondeque não quer um bolo de fubá e sim um bolo feito de milho da escola". E, ainda, disse que ela fica pedindo para que todos tenham cuidado com as plantas, pois elas precisam de carinho.

Conforme depoimento de outra mãe, a do al uno Rafael, que plantou o feijão em casa, "Foram vários pés de feijão, que tudo que vê el e quer plantar, inclusive arroz; gosta de cuidar das plantas, e isso el e começou assim que plantaram o milho" (Trecho do relatório).

Noutra reunião, novas manifestações dos pais, após terem visto a plantação:

- Meu filho mudou completamente seu comportamento para mel hor, pois anteriormente el e não brincava, não tinha amigos, não era muito de sorrir ou comentar. Hoje ele comenta muito sobre o milho, convidou um amigo, Danilo, da própria classe, e não gosta de faltar (Depoimento da mãe do aluno Gabriel). 
- Gabriel jáé um excel enteal uno, lêtudo; na classe, este aluno conversa pouquíssimo, mas nota-se que, ao sair para o recreio, ele fica com vários coleguinhas, principalmenteo Tiago, e, ao visitar o milho, ele é um grande observador. Comentei coma mãequeelenão quis colocar esterco, e a mãe respondeu que ele real mente não gosta de sujar as mãos (Depoimento da professora).

As reuniões mostraram o carinho e o respeito queas crianças tiveram não só com o milho, mas com as plantações em geral, além da vontade deplantar.

A proveitamos para medir a al tura do miIho. Primeiro o fizemos escolhendo uma aluna cuja altura mais se aproximasse dela, e todos perceberam que era a Aninha. Tiramos foto e, na classe, medimosa al una. Um al uno observou que a Aninha era um pouquinho mais al ta que o milho. Elogiei sua observação. Ao medir a Ana $(1,12 \mathrm{~m})$, fal ei de sua medida, e, como ela era um pouco mais alta, deduzimos que o milho seria mais ou menos $1,10 \mathrm{~m}$. Eles desenharam.

O al uno Rafael perguntou-me se poderia trazer o feijão que havia plantado, aí perguntei porque eletinha feito isso. Elerespondeu que achou legal plantar, e que seu feijão estava grande. Isto demonstra que o trabal ho desenvolvido despertou interesse (Trecho do relatório).

Para marcar a data da festa final, trabaIhou-seo cal endário desdeo início da plantação, respondendo perguntas como: Em que mês plantamos o milho? Em que dia do mês? Em que dia da semana? Em que mês vimos o pendão? Em que dia do mês? Em que dia da semana? Quantos dias o milho levou para dar o pendão?

Os al unos participaram ativamente, e aaulafoi muito proveitosa. Como tarefa para casa, os al unos pesquisaram: a) quais os tipos de milho que conheciam; eb) o quea mamãe podia fazer com o milho.

$\mathrm{Na}$ classe foram dadas e discutidas questões como: O fubá é feito de quê? A pipoca é feita de quê? A canjica éfeita de quê? O curau éfeito de quê? A pamonhaé feito dequê?

Também escreveu-se na lousa o tema "espiga de milho", e, com essas palavras, os al unos montaram novas palavras, isto é, movendo as letras. Para aqueles al unos com muita dificuldade na escrita foram dadas outras pal avras simples ou mesmo brincadeiras com as vogais.
Com base em uma outra história, também relacionada ao milho - "o milho e o pássaro" - os desenhos foram copiados e passados para os al unos, com o pedido de que observassem bem a seqüência dos desenhos, dessem nomes aos personagens e criassem uma história. Os resultados foram excelentes.

Numa das reuniões com os pais, procurou-se saber deles as impressões que puderam extrair dos alunos em casa. Os resultadoscol hidos foram excelentes eincentivaram a continuidade do projeto.

No dia 10 de maio tivemos uma reunião com os pais. E levei as fotos para eles verem. Gostaram muito. Perguntei se os filhos haviam comentado sobre nossa plantação de mi lho, e os depoimentos de al guns pais foram surpreendentes.

A mãe de Tânia: "Minha filha sempre fala que não vê a hora que tenha milho, pois quer fazer o bolo". E a mãe disse: "Filha, eu faço bol o de fubá pra você. Ela respondeu que não quer um bolo de fubá e sim um bolo feito de milho da escola". E, ainda, a mãe fal ou que ela fica pedindo para que tenha cuidado com as plantas, pois elas precisam de carinho. Também essa al una não gosta defaltar às aul as. Ela apresenta muitas dificuldades, isto é, ela ainda não atingiu os parâmetros mínimos, mas uma criança que consegue exigir da mãe cuidados com as plantas e quejá tem assiduidade certamente estará superando as dificuldades também na escrita.

Ospais do Rafael, aquelequedissehaver plantado fejjão, relataram que o filho despertou paraaimportância das plantas desdequeiniciamosnossasatividadesaqui naescola. Plantou vários pés de feijão e de arroz e gosta de cuidar das plantas.

E, assim, foram vários os pais que deram depoimentos (Trecho do relatório).

Dois dias após a reunião com os pais, aproveitamos para discutir a questão do adubo natural esterco, destacando as suas propriedades.

Mais tarde, no mesmo dia, foi real izada a reunião com os pais que não haviam comparecido à reunião anterior, e, novamente, os resultados foram positivos.

No dia 12 de maio, fomos à plantação do milho e verificamos que as raízes estavam fora da terra. Comentei que se deixássemos assim elas morreriam. Começamos a 
pegar esterco e colocar nas plantas. Nesse local havia muito esterco. Expliquei que eram estrumes de animais (vaca e cavalo) e que era rico em vitaminas para as plantas, pois esses animais só se al imentavam de mato e água. Muitos tiveram nojo; outros foram com muito fervor. Não obriguei ninguém, mas os alunos queajudavam recriminavam os que não estavam ajudando, e, por fim, alguns quenão estavam colaborando resolveram pegar nem que fosse um pouquinho. Depois as crianças desenharam (Trecho do relatório).

Neste mesmo dia, às $17 \mathrm{~h}$, fiz outra reunião com alguns pais que não haviam comparecido na anterior. Aliás, foram somente oito pais na primeira reunião. Mas esqueci detrazer as fotos, e, então, os convidei para irem pessoal mentever nossa plantação. Eles gostaram muito. Nessa tarde compareceram o pai do Tiago e a mãe do Gabriel.

A mãe do Gabriel disse que o filho dela mudou completamente de comportamento, para melhor, pois anteriormente ele não brincava, não tinha amigos, não era muito de sorrir ou comentar. Hoje, ele comenta muito sobre o milho, convidou um amigo (Danilo) da própria classe para ir à sua casa, fazem as lições juntos. A mãe está feliz com o desempenho do fiIho. Ele já é um excel ente al uno; lêtudo, na classe conversa pouquíssimo, mas nota-seque, ao sair para o recreio, el efica com vários coleguinhas, principal mente o Tiago, e, ao visitar o milho, ele é um grande observador. O pai do Tiago também fal ou do seu desempenho. Está muito satisfeito com a transformação que a escol a está provocando, etudo queel efaz na escola comenta em casa.

O quemais gostei nestas reuniões foi o carinho e o respeito que as crianças tiveram não só com o mil ho, mas comas plantações em geral, e a vontade de plantar, embora muitos reclamem da falta de espaço em casa para plantar (Trecho do relatório).

Tanto no final do primeiro bimestre como no do segundo foram formuladas questões como as transcritas abaixo:

1. Você notou alguma mudança nas atitudes deseu(sua) filho(a) nessebimestre?

2. Quais foram os aspectos positivose quais os negativos?
3. Seu(sua) filho(a) tem tido problemas em al guma ou al gumas disci plinas? Quais?

4. Gostaríamos que fossem feitas al gumas sugestões para a melhoria do ensino em nossa escola.

A avaliação dos pais, em reuniões nos dois bimestres, foi positiva, eas manifestações relacionadas são as seguintes:

Despertou emseusfilhosa vontadedeplantar, tanto que estes desejam também plantar em casa qual quer semente quel hes caem às mãos, mas principal menteo milho, parafa zer um bolo de milho.

No segundo momento é que sentiram em seus filhos mudanças comportamentais, ou seja, entrosamento com outras crianças, interesse por historinhas e leitura, vontade de ir à escola (1o Bimestre).

Quetenha mais projetos como o projeto da gal inha ruiva, mas com batata, feijão, etc.

Que a plantação foi uma aprendizagem muito importante para seu filhos.

Queos fil hos mudaram seu comportamento para mel hor em casa e passaram a demonstrar interesse pelo teatro, leitura e, em geral, pela escola.

Que acompanharam mesmo de longe eficaram emocionados e com água na boca, devido aos comentários que seus fil hos fizeram da escola ( 2 o bimestre).

Alguns dias após foram feitas novas visitas ao milharal. Na primeira, procuramos apresentar e discutir as partes das plantas.

No dia 25 de maio, fomos visitar o milho e foi uma gritaria, pois o milho havia dado seus primeiros pendões; aliás, dois pés de milho. Eles pulavam, davam graças a Deus e sorriam. Corri para pegar a máquina fotográfica, poiseu nem pensava em fotografar atéo momento, ea própria diretora veio comparti lhar a al egria dos al unos. Um aluno disse que foi por causa do adubo que o milho deu o pendão. E os outros já pediam para colocar mais adubo. Teve um que verificou que a raiz estava novamente aparecendo, e, enquanto eu conversava com a diretora (Leni), eles regavam e colocavam esterco. Tiramos fotos com eles trabal hando e, ao chegar na classe, eles desenharam com muito entusiasmo. A proveitei para novamentefal ar das partes das plantas - raiz, caule, flor efrutos - eperguntei o que estava faltando no nosso pé de milho, e eles responderam que era o fruto. Nesta hora uma aluna (Ingrid) disse que, quando o 
mil lho desse o fruto eo bol o fossefeito, gostaria delevar um pedaço de bolo para seus dois irmãos (Trecho do relatório).

Na segunda visita rediscutimos o calendário para os meses de março a maio e formulamos uma série de questões previamenteelaboradas.

No dia 26 de mai o trabal hamos o calendário dos meses de março, abril e maio. E os passos foram:

Primeiro dei uma folha somente quadriculada para cada aluno e expliquei que uma semana tem sete dias e coloquei os dias da semana na lousa. Na fol ha quadriculada colocamos juntos as iniciais da semana. Comentei que havia meses que têm $28,29,30$ ou 31 dias e que um ano tem 12 meses, escrevi os meses na lousa. Mas iríamos trabal har somente os meses de março, abril e maio. Assim que construímos o calendário, eu na lousa eas crianças com seu papel, demos destaque para o dia 10 de março, dia que plantamos o milho. E destacamos também o dia 25 de mai o, que foi o dia em que vimos o pendão (mas expliquei que possivelmente teria nascido no fim de semana, mas como vimos nesse dia o destacaríamos). Assim que terminamos o calendário, fiz as segui intes perguntas (os al unos ol havam no calendário, respondiam e eu escrevia na lousa): a) Em que mês plantamos o miIho? b) Em que dia do mês? c) Em que dia dasemana? d) Emquemês vimoso pendão? e) Em que dia do mês vimos o pendão? f) Em que dia da semana? g) Quantos dias o mil lho levou para dar o pendão? (Trecho do relatório)

Finalmente, naterceira visita consecutiva, aproveitamos para desenvolver trabaI hos de pesquisa eal fabetização.

No dia 27 demaio, assim queentramos na classe, fomos visitar o milho, pois as crianças estavam ansiosas para acompanhar o seu desenvol vimento. Em cada pé de miIho já havia três espigas. Subimos para a classe e eles desenharam o que viram. Recordamos as partes da planta e o que elas precisam para um bom desenvol vimento. Para casafoi pedidauma pesquisa. Asquestões foram as seguintes: O fubá é feito de quê? A pipoca é feita de quê? A canjica é feita de quê? $O$ curau é feito de quê? $A$ pamonha é feita de quê? Além dessas perguntas, contei algumas novidades que aprendi lendo (incentivando a leitura), que do milho aproveitamos quase tudo. Por exemplo, usa-se a fol ha da espiga do miIho para enrolar a pamonha, e, quando seca, a chamamos de pal ha - dela são fei tos cigarros, que o cabelo de milho é muito usado para chás (diurético) e que o sabugo é utilizado em rações para animais e dela também se faz placas acústicas. Como as crianças têm o alfabeto móvel, eu coloquei na lousa "espiga de milho", e eles montariam com essas palavras novas palavras, isto é, movendo as letras. Para aqueles al unos com muita dificul dade na escrita, dei outras palavras brincando com as vogais. Eu ia (com os al unos) tirar foto, mas tínhamos muita tarefa, e aí eu pedi para Anésia tirar foto da espiga de milho (Mais um trecho).

Depois, continuamos o processo de alfabetização, inclusive como auxílio detexto retirado de uma cartilha. Justifica-seo ato de utilizar o texto da cartilha com basena cita ção das autoras Angela B. Kleiman e Silvia E. Moraes (1999, p. 67):

O texto do livro didático tem uma função importante como base científica para auxiliar na interpretação de textos multidisciplinares como os das revistas e jornais. Embora haja livros didáticos, seus problemas subsistem quando são utilizados exclusi vamente.

Também, aproveitando-se das espigas de mil ho que havia no "milharal" e das novas que apareceram, pôde-se trabalhar as "continhas".

No dia 28 de maio, as crianças insistiram em ver o milho. Estavam muito ansiosas. Fomos ver. Eles ficaram maravilhados com o cabel o do mil ho bem clarinho. Hoje não desenhamos, pois no desenho anterior eles já haviam notado o pequeno cabelo. Trabal hei, então, um texto: "Cresci e vou ser mamãe". Ganhei este texto da professora Vera, que o retirou de uma antiga cartilha - Caminho suave, de Branca Alves de Lima. Tirei xerox, lemos o texto, expliquei algumas palavras, e eles pintaram. As crianças gostaram muito da história, e eu mostrei o texto seguinte, que só daria na segunda feira. Eles ficaram curiosos, pois disseram queera linda a história. Pedi para que não faltassem na segunda.

No dia 1 을 de julho fomos novamentevisitar o milho, e observamos que as espigas de mil lho aumentaram, porque naúltima contagem havia 22 espigas e agora tínhamos 35 espigas. A pós esta atividade, fomos para a classe e trabalhamos Matemática, com problemas e, depois, com o cal endário. 
Ex::

Havia 22 espigas de milho

Cresceram mais 13 espigas.

Quantas espigas eu tenho agora? (Trechos do relatório)

Como parte do projeto, os al unos dramatizaram o trabal ho para outras classes da escola, mostrando-o com utensílios edecoração improvisada por el es próprios.

A representação permitiu concluir que, a partir do momento em que a criança interioriza a história, nada é estranho para ela.

No dia 2 de julho, apresentamos o teatro para as outras classes; os al unos haviam feito o painel do milharal, e eu fiz o fogão a lenha (com papelão), emprestei utensílios (panela de ferro, chaleira de ferro, ferro de passar roupa, toal ha de papel decorada com recortes de várias formas, como se usava antigamente, feita pela professora Regina Célia), vassoura de mato, canequinhos esmaltados, gamela, colher de pau; para decoração da prateleira, também usei uma miniatura do carro de boi e, finalmente, o forno a lenha, feito com cartolina.

E para a peça ficar mais "real", arranquei a primeira espiga de milho e as crianças não gostaram - ouvia-se um murmúrio: "Ah! Ah! Ah! Coitadinho!"

O mais interessante foi que a decoração foi totalmente improvisada; apenas o painel era conhecido pelas crianças, pois foram eles mesmos que o confeccionaram. Quando tínhamos ensaio não havia nada de decoração, pois o mesmo erafeito ou na sala de aula ou na quadra. E neste dia os alunos apresentaram a peça com tanta natural idade, usando os utensíli os como se fossem da época em que el es vivem. A única coisa que el es confundiram foi o forno a lenha. Muitos foram e bateram na porta do forno (a lenha), como sefosse a porta de uma casa; ea cada equi pe que ia apresentar eu frisei: "Isto é um forno usado antigamente!" Mesmo assim, só a última equipe não confundiu o forno. Cheguei à conclusão de que, a partir do momento que uma criança interioriza a história, nada é estranho para ela. Neste dia também algumas crianças que participavam da equipe faltaram (Rosa, Carlos eRenan). Uns porqueestavam doentes, outros não fal aram o motivo. E as equipes que estavam sem esses el ementos substituíam com facilidade com outra criança (Nathália, Thiago, Jefferson), que não haviam ensaiado. Eles participaram por vontade própria. Mais uma vez repito que a criança que compreende a história desempenha com tranqüilidade uma dramatização.

No dia 6 de jul ho os al unos assistiram seu próprio trabal ho. Ficaram encantados, riram bastante e aplaudiam. À medida que cada equipe apresentava, parecia que as crianças estavam vivenciando aquel emomento outra vez. Na sal a de aula pedi que desenhassem as etapas da história da gal inha ruiva; depois passei um trecho da música da história (Trecho do relatório).

No final do projeto fez-seo tão esperado bolo demilho, com a receita nal ousa eaproveitando, para atividades, como retirar do texto palavras com ch- Ih- nh-, de onde vem o sal, a diferença entrea manteiga ea marga rina, higiene, importância dos alimentos, colaboração do trabal ho em conjunto, etc.

No dia 28 de julho fizemos final mente o tão esperado bolo. Primei ro vi quantas crianças estavam presentes, e chamei a exal una Josienne- ela participou do plantio e estava em outra classe, porque foi reclassificada.

O total foi de 30 al unos; fal taram três. Pedi que fizessem três equipes com dez alunos, e eles mesmos se organizaram (Trecho do relatório).

A etapa final foi bastante gratificante. A receita foi novamenterepassada na lousa, juntamentecom uma série deatividades:

a) Cópia da receita.

b) Retire do texto palavras com: ch- Ih- nh-.

c) Quais os animais que você conhece que botam ovos?

d) Quais os animais que dão leite?

e) Qual é a diferença entre manteiga e margarina?

f) De onde vem o sal?

g) Cite cinco coisas que podem ser feitas com o milho.

h) Faça um desenho (livre) e cole grãos de milho (canjica, milho comum e de pipoca).

O preparo do bol o continuou, enquanto questões eram formuladas. 
A equipe que fazia o bolo tinha que ler e entender o que estava lendo. Eu fazia al gumas perguntas: "Tenho que colocar o ovo inteiro com casca no bolo?" "Qual a diferença entre a manteiga e a margarina?" "Vocês ajudam a mamãe em casa?" Assim todos colaboraram, até na limpeza. Algumas crianças queriam experimentar a sobra crua da tigela. O cheiro do bolo invadiu a escola, e muitos professores e funcionários falavam: "Ah! Que cheiro gostoso! Quero um pedacinho do bolo". Comentei com os alunos sobre o nosso sucesso e que nós daríamos um pedacinho de bolo para alguns funcionários e professores. Os al unos não reclamaram; compartilharam com al egria (Trecho do relatório).

O preparo do bol o foi concluído, einiciamos o aguardado momento de servi-lo.

Na hora de comermos o bolo, cantei a música principal da historinha: "Quem me ajuda, quem me ajuda, a comer esse bolo?" A resposta foi unânime: "Eu sim, sim, dona galinha" (bis). Os gritos dealegria e as pal mas foram muitos na chegada dos bol os. Cada al uno ganhou dois pedaços, e o mais interessante foi que muitos falaram que iam levar para a mãe deles. Agradecemos às pessoas que nos ajudaram até aqui: dona Leni (diretora), dona Anésia (coordenadora), Maurício (caseiro) e dona Roberta, quefilmou nossas atividades com muito carinho (Trecho do relatório).

O final da festa foi muito alegre, de monstrando a satisfação dos al unos.

E enquanto fal ávamos das pessoas, as crianças aplaudiam. Comeram do bolo, mas, antes de o comermos, muitos fal aram: "Posso lavar minhas mãos, professora?" Nota-se que estão entendendo de higiene também. Depois, na hora de comer, uns corrigiam o outro: "Olhea boca, temos quecomer coma boca fechada". E para brincar com eles eu falei que aquele momento estava parecendo o programa Note e anote. E as crianças falaram que só fal tava me esconder embaixo da mesa - e eu o fiz. Eles riram bastante (Trecho do relatório).

Ainda aproveitamos para uma revisão das questões tratadas, com o objetivo de enriquecer as aulas.

No dia 29 dejulho eu dei uma revisão nas questões anteriores pois muitos não haviam terminado; dei um "caça-palavras" para enriquecer mais as aulas, e fizemos, juntos, as atividades:

Caça-Pal avras:

1) Fruto que dá no milharal.

2) Líquido que sustenta animais mamíferos ao nascer.

3) Pó químico usado para fazer pães e bolos crescerem.

4) Produto usado para sal gar al imentos.

5) Creme vegetal usado para passar no pão e colocar em massa de bolo.

6) Produto retirado da cana e usado para adoçar alimentos.

7) $\mathrm{O}$ que a ave e alguns animais põem e servem como alimentos.

8) Cereal reduzido ao pó.

ABSDEJUMILHOBE
FERMENTOTOUNAI
SMARGARINATLMA
AÇUCARTRIDDKTEI
MOVOOAPATEMTIA
FARINHADEQUALQ
BOLODISALMICOT
CIALEITECOMNES
(Conforme o relatório)

Os alunos se sentiram muito motivados, seus conhecimentos foram val orizados eo trabal ho deles reconhecido.

No dia 2 de agosto fomos novamente visitar o restante da horta, pois muitos pés deveriam ser arrancados por já estavam secos. Uma aluna, Bruna, estava reclamando para outra: "Tivemos tanto trabaIho para plantar, cuidar, colher e agora tem que estragar a natureza?" Respondi: "É necessário, pois alguns pés já morreram. Também há classes de outras séries que precisam plantar". Daí foi decidido com a dona Leni que os pés que ainda tinham espigas de milho deveriam ficar e os outros poderiam ser arrancados.

No dia 11 de agosto, eu passei o filme para que os al unos assisti ssem ao trabaIho da colheita e do bolo; a reação foi igual à anterior. Eles aplaudiram seus feitos, fixavam seus ol hares e sorriam. E a Thais Fernanda fal ou: "Vamos plantar mais, professora?"

Os pais dos al unos assi stiram a esse filme no dia 13 de agosto; muitos já fizeram comentários e escreveram logo após o bolo demilho. Os relatórios estarão anexados a este trabalho. O primeiro comentário foi uma surpresa para mim; eu fiquei emocionada. Aos outros eu pedi que analisassem esse "Projeto da Galinha Ruiva", os 
pontos positivos e negativos, bem como o andamento geral neste primeiro semestre. E em um deles a mãe quer que eu faça outros tipos de plantações, pois incentiva muito aquela criança que vive na cidadee só conhece al imentos industrial izados.

Foi muito gratificante e produtivo (Parte final do relatório).

O projeto permitiu que os conteúdos curriculares fossem trabal hados sem que fossem tratados isol adamente ou em compartimentosfixos.

Os temas abordados durante todo o processo podem ser arrolados como: folclore, dramatização, criatividade, trabalho em equipe, assiduidade, col aboração, ética e respeito, desenho e arte, plantação, aritmética, medidas, adubos e fertilizantes, densidade, ciências emeio ambiente, higieneesegurança no trabal ho, fotografia, pesquisa, experiência in vitro, registro das observações, al fabetização eleitura.

\section{Conclusões}

Os objetivos inicial mentetraçados para a proposta foram al cançados em todas as etapas do trabal ho, visando o envolvimento da criança na busca pessoal do saber, favorecendo a auto-estima ediscutindo val ores, tendo por finalidade a formação do cidadão crítico e colaborativo.

No decorrer do trabal ho de campo obtivemos um material bastante vasto, quenão seria possível transcrever em toda a sua amplitude, dadas as limitações deespaço de umartigo. Daí procurarmos registrar apenas aspectos esituações queconsideramos mais relevantes, valendo-nos do minucioso relatório el aborado como parte do projeto.

O trabal ho desenvolvido preocupouse em pensar o ensino e a aprendizagem dentro de um contexto cultural amplo, buscando rel acionar o que é aprendido dentro efora da escola.
As questões curriculares foram trabaIhadas de forma interdisciplinar e transversal , evitando a compartimental ização do conhecimento e levando os al unos ao meIhor aproveitamento. Os temas abordados permitiram às crianças adquirir os conhecimentos vivenciados e os previstos curricularmente.

No entanto, a proposta de trabal ho escolar situou-se além das preocupações alienantes eindividual istas do currículo tra dicional , articulando as diferentes áreas do conhecimento. Configurou-senuma prática deorganização do trabal ho escolar queconseguiu fazer faceà fragmentação, à al ienação e ao individual ismo do currículo. Também, questões relevantes para a vida social estiveram presentes no dia-a-dia dos alunos, como se pôde discutir amplamente ao longo do trabal ho.

O trabal ho desenvol vido permitiu que as atividades curriculares considerassem a aprendizagem conceitual e a prática social mais autênticas, uma vez que refletiram a vida real - fator bastante motivador para o processo deensino-aprendizagem.

Os depoimentos dos pais vieram confirmar as observações durante o desenvolvimento do projeto, ou seja, que os alunos gostaram, envol veram-se, val orizaram o tra bal ho em grupo, estudaram mais, apresentaram mudanças comportamentais elevaram aos pais a satisfação do que estavam fazendo e aprendendo.

O trabal ho etnográfico desenvolvido procurou descrever o ambiente social dos al unos, as ativi dades gerai s e o ambientefísico, al ém de preocupar-se, desde o início, com o registro de dados, el aborando-se um rel atório bem compl eto e que permi tiu a re dação destetrabal ho.

Retomando à introdução do texto e as razões que levaram a publicá-lo, podemos concluir que o projeto da "galinha ruiva" ensinou muito aos al unos, aumentando o conhecimento deles sobreo mundo queos cerca, levando-os ao prazer da escol a eà necessária sol idariedadeerespeito ao trabal ho, tornando-os sensíveis à bel eza da natureza.

\section{Referências bibliográficas}

ALVES, Rubens. Sobre moluscos, conchas e beleza. Folha de S. Paulo, 31 mar. 2002. p. A3.

KLEIMAN, Angela B.; MORAES, Silvia E. Leitura e interdisciplinaridade: tecendo redes nos projetos da escola: Campinas: Mercado de Letras, 1999. 191 p. 
LÜDKE, Menga; ANDRÉ, Marli E. D. A. Pesquisa em educação: abordagens qualitativas. São Paulo: EPU, 1986. 99 p. (Temas básicos de educação e ensino).

PARÂMETROS CURRICULARES NACIONAIS (1a A 4a SÉRIE). Apresentação dos temas transversais. Brasília: MEC/SEF, 1997.

SAVEDRA, Vera Lucia Alves; CAVA, Patricia Pereira. Estigma e escola: um estudo sobre o aluno considerado problema. In: CONGRESSO DE INICIAÇÃO CIENTÍFICA DA ASSER, 5., São Carlos-SP, 2000. Anais... São Carlos, nov./dez. 2000. p. 127.

Hilda Rabel o de Oliveira, graduada em Pedagogia pel o Centro Universitário Central Paulista (Unicep) de São Carlos (SP), é professora do ensino fundamental e leciona na EEPG "Prof. Bento da Silva César" dessa cidade.

Alberto N. Senapeschi, doutor em Ciências pela Universidade deSão Paulo (USP), é professor do curso de Pedagogia do Centro Universitário Central Paulista (Unicep) deSão Carlos (SP).

posgraduação@asser.com.br

\section{Abstract}

The work here presented was developed with seven-year-old children, primary school students at "Escola Estadual Prof. Bento da Silva César", in suburban São Carlos. The project objective was to work out curricular contents without allowing them to be fragmented, but using interdisciplinarity and transversality during the entire project. It was also aimed that children developed taste in school and work. The students were very motivated during the project and curricular issues as alphabetization and reading, measurements and arithmethics, science and environment, drawing and creativity, arts, work and mutual respect, ethics and research, have always been present, treated in the proposed methodology for this project.

Keywords: interdisciplinarity; transdisciplinarity; pedagogy in the project; intertextuality.

Recebido em 18 de junho de 2002.

A provado em 24 de junho de 2003. 